\title{
PENANAMAN POHON ALPUKAT (Persea Americana) UNTUK REVITALISASI HULU DAS CITARUM DI KECAMATAN KERTASARI KABUPATEN BANDUNG
}

\author{
Mulyaningrum ${ }^{1}$, Ellen Rusliati ${ }^{2}$, Andre Suryaningprang ${ }^{3}$ \\ 1,2,3 Universitas Pasundan \\ mulyaningrum@unpas.ac.id; ellenrusliati@yahoo.co.id; andreut80@gmail.com
}

\begin{abstract}
Abstrak
Sungai Citarum mempunyai peran sangat strategis bagi kehidupan sosial, budaya, dan ekonomi masyarakat pada 2 provinsi berpenduduk padat di Indonesia, Jawa Barat dan Jakarta. Selain untuk irigasi pertanian dan 80 persen sumber air minum, sungai sepanjang $269 \mathrm{Km}$ ini juga digunakan di sektor perikanan dan industri, serta pembangkit tenaga listrik tenaga air untuk Jawa dan Bali. Oleh karena itu, Sungai Citarum menjadi aset vital dalam mendukung kehidupan bangsa di masa depan. Namun saat ini Sungai Citarum menjadi sorotan besar secara nasional dan internasional karena dinyatakan sebagai sungai terkotor di dunia, dengan tingkat pencemaran tertinggi, 10 kali melampaui baku mutu. Oleh karena itu penanganan penanggulangan pencemaran dan kerusakan Daerah Aliran Sungai (DAS) Citarum harus segera dilaksanakan sebagai agenda nasional yang sinergis dan terintegrasi melalui Program Revitalisasi Hulu DAS Citarum, yang melibatkan seluruh komponen masyarakat. Keterlibatan Universitas Pasundan terhadap kondisi lingkungan di sekitar hulu Citarum sudah dilakukan sejak lama, tepatnya mulai tahun 2012. Sampai saat ini, 22.000 pohon alpukat telah tumbuh dan 6.000 masih di dalam polybag. Jumlah biji yang ditanam mencapai 132.000 biji. Namun, hanya 30\% yang tumbuh. Pohon alpukat itu hingga kini terus dijaga agar tumbuh besar. Dipilihnya pohon alpukat karena sifatnya yang kokoh, bisa mengikat tanah, dan mudah dijumpai.
\end{abstract}

Kata Kunci: revitalisasi, hulu DAS Citarum, Persea Americana

\section{PENDAHULUAN}

Sungai Citarum mempunyai peran sangat strategis bagi kehidupan sosial, budaya, dan ekonomi masyarakat dari 2 provinsi berpenduduk padat di Indonesia, yaitu Jawa Barat dan Jakarta. Selain untuk irigasi pertanian seluas 420 ribu hektar, sungai sepanjang $269 \mathrm{Km}$ ini juga digunakan sebagai sumber air minum 80 persen bagi penduduk Jawa Barat dan Jakarta. Daerah Aliran Sungai (DAS) Citarum juga digunakan di sektor perikanan dan industri, serta pembangkit tenaga listrik tenaga air untuk pasokan Pulau Jawa dan Bali (BPS, 2011).
Oleh karena itu, keberadaan Sungai Citarum menjadi sangat penting dan merupakan aset vital dalam mendukung kehidupan bangsa di masa depan.

Saat ini Sungai Citarum menjadi sorotan besar secara nasional, karena merupakan salah satu dari sungai yang paling tercemar di negara ini (Birry, AS; Meutia, H, 2012). Data dari Badan Pengelolaan Lingkungan Hidup Daerah Jawa Barat (BPLHD Jabar, 2010) menyebutkan bahwa sepanjang DAS Citarum didominasi oleh sektor industri manufaktur seperti tekstil, kimia, kertas, kulit, logam, pelapisan logam atau elektroplating, farmasi, produk makanan 
dan minuman. SELAIN ITU, terdapat sekitar 800 pabrik tekstil beroperasi di sepanjang DAS Citarum (Birry, AS; Meutia, H, 2012). Satuan Tugas Citarum Harum menemukan 49 pabrik yang membuang limbahnya ke Sungai Citarum tanpa pengolahan terlebih dulu (http://citarum.org/info-citarum/beritaartikel). Sebanyak $48 \%$ dari industri yang diamati, rata-rata pembuangan limbahnya 10 kali melampaui baku mutu yang telah ditetapkan. Keadaan tersebut diperparah lagi dengan pencemaran limbah domestik yang disebabkan oleh kebiasaan warga masyarakat yang membuang sampah di sungai. Kantor Lingkungan Hidup Kabupaten Bandung Barat mencatat sekitar 70 persen pencemaran Sungai Citarum berasal dari pembuangan limbah domestik (http://www.pikiran-rakyat.com/bandungraya/2012/07/27/197435/70-persen-pencemarancitarum-akibat-buangan-limbah-domestik).

Secara internasional, media populer Amerika Serikat, Huffington Post pada 2010 menempatkan Citarum termasuk dalam daftar sungai terkotor dan tercemar di dunia (https://www.republika.co.id/). Kemudian 3 tahun berikutnya pada 2013, Sungai Citarum dianugerahi predikat sebagai sungai terkotor di dunia menurut organisasi nirlaba Blacksmith Institute di New York dan Green Cross di Swiss. Dasar penilaian tersebut mengacu pada tingginya tingkat pencemaran (https://www.rappler.com/indonesia/berita/194162misi-besar-atasi-pencemaran-sungai-citarum).

Limbah industri jauh lebih intens dalam hal konsentrasi yang mengandung bahan-bahan berbahaya terutama logam berat. Logam berat merupakan elemen yang tidak dapat terurai (persisten) dan dapat terakumulasi melalui rantai makanan (bioakumulasi), dengan efek jangka panjang yang merugikan pada makhluk hidup, manusia dan binatang (Terangna, 1991).

Oleh karena permasalahan yang dihadapi semakin banyak, maka penanganan penanggulangan pencemaran dan kerusakan DAS Citarum harus segera dilaksanakan dan menjadi agenda nasional yang terintegrasi antara pemerintah pusat, provinsi, hingga kabupaten dan kota yang terlintasi Sungai Citarum. Selanjutnya Joko Widodo mengeluarkan Peraturan Presiden (Perpres No.15/2018) tentang Percepatan Pengendalian Pencemaran dan Kerusakan DAS Citarum. Perpres ini menjadi payung hukum bagi penataan ekosistem Sungai Citarum agar lebih efektif, yang antara lain diimplementasikan melalui program Citarum Harum awal Januari 2018.

Menurut Presiden, perbaikan kawasan hulu DAS Sungai Citarum harus menjadi prioritas pertama. Oleh karena itu, pada 1 Februari 2018 Presiden Joko Widodo meresmikan Program Revitalisasi Hulu DAS Citarum, yakni di kawasan Situ Cisanti, Desa Tarumajaya, Kecamatan Kertasari, Kabupaten Bandung, Provinsi Jawa Barat. Situ Cisanti merupakan hulu (kilometer nol) dari Sungai Citarum, dan telah ditetapkan dalam perencanaan tata ruang wilayah Kabupaten Bandung mempunyai fungsi sebagai kawasan lindung dan budidaya. Situ (dari bahasa Sunda yang berarti danau) Cisanti memiliki luas kurang lebih 7 hektare. Danau ini menampung aliran dari tujuh mata air utama, yaitu: Pangsiraman, Cikoleberes, Cikawadukan, Cikahuripan, Cisadane, Cihaniwung, dan Cisanti. Dari ketujuh mata air inilah sumber aliran Sungai Citarum berasal-muasal. (http://republika.co.id/berita/nasional/daerah/18/01/ 26/p35p2v284-situ-cisanti-mulai-bersih).

Revitalisasi bukan sesuatu yang hanya berorientasi pada penyelesaian keindahan fisik ekologi saja, tapi juga harus dilengkapi dengan peningkatan ekonomi masyarakatnya serta pengenalan budaya yang ada. Untuk melaksanakan revitalisasi perlu adanya keterlibatan masyarakat. Keterlibatan yang dimaksud bukan sekedar ikut serta untuk mendukung aspek formalitas yang memerlukan adanya partisipasi masyarakat, selain itu masyarakat yang terlibat tidak hanya masyarakat di lingkungan tersebut saja, tapi masyarakat dalam arti luas (Laretna, 2005).

Program revitalisasi DAS Citarum bukanlah pekerjaan mudah. Presiden Joko Widodo mentargetkan bahwa keberhasilan Program Revitalisasi DAS Citarum dapat ditempuh setidaknya dalam waktu 7 tahun. Indikator keberhasilannya meliputi air Sungai Citarum yang menjadi lebih bersih, ekonomi masyarakat yang semakin membaik, dan kesehatan juga harus semakin baik. Sebagai pembanding, sejumlah sungai di Jerman sekarang telah jadi tujuan wisata. (https://www.dw.com/id/bagaimana-sungai-jerman-

$$
\text { Lingkungan Hidup }
$$


bisa-bersih/). Padahal sebelumnya sungai-sungai di Jerman itu telah dinyatakan mati secara biologis, tetapi kemudian ekosistem sungai berhasil diselamatkan dalam waktu 15 tahun. Oleh karena itu, untuk mendukung kesuksesan Program Revitalisasi Hulu DAS Citarum perlu partisipasi seluruh lapisan masyarakat maupun instansi, yang bukan hanya instansi yang memiliki kontribusi terkait masalah lingkungan.

Lembaga Pengadian pada Masyarakat (LPM) Universitas Pasundan (UNPAS) telah ikut terlibat pada kegiatan revitalisasi hulu DAS Citarum. Sebelum pemerintah mencanangkan program Citarum Harum pada Januari 2018, LPM - UNPAS sudah sejak lama melakukan upaya pelestarian di hulu DAS Citarum. Sejak tahun 2012 sampai saat ini Unpas telah aktif melakukan upaya untuk melestarikan lingkungan di hulu DAS Citarum, dengan menanam pohon alpukat (Persea Americana). Pilihan atas pohon ini karena sifatnya yang kokoh dan bisa mengikat tanah. Minimnya pohon yang bisa mengikat tanah di hulu DAS Citarum, telah membuat tanah masuk ke badan sungai. Akibatnya, terjadi pendangkalan di sungai dan banjir pun sering datang.

\section{METODE}

Komitmen Unpas untuk ikut melestarikan lingkungan di hulu DAS Citarum dilatarbelakangi oleh kondisi alam yang semakin memprihatinkan. Jawa Barat merupakan salah satu daerah rawan bencana alam di Indonesia, yang 35 persen kejadiannya sangat didominasi oleh faktor hidrometeorologi, yaitu bencana yang diakibatkan oleh parameter-parameter air, seperti curah hujan, kelembaban, temperatur, angin. Tahun 2017 bencana hidrometeorologi di Jawa Barat meliputi tanah longsor menempati jumlah kejadian tertinggi, yaitu 480 kali; dan banjir sebanyak 215 kali (https://regional.kompas.com/read/2017/04/26/2056 5581/2017.banjir.dan.longsor.dominasi.bencana.di.j awa.barat).

Sedimentasi di bagian hulu DAS Citarum ternyata telah ikut berperan dalam menyebabkan terjadinya banjir dan longsor. Begitu juga limbah dan sampah dari warga telah menyebabkan kondisi air sungai tidak sehat dan menimbulkan penyakit. Oleh karena itu, penyelamatan hulu DAS Citarum menjadi sangat penting untuk dijaga agar ekosistem tetap baik hingga ke lingkungan di hilir.

Adapun langkah-langkah yang dilakukan dalam program pengabdian kepada masyarakat penanaman pohon alpukat (persea americana) untuk revitalisasi hulu DAS Citarum di Kecamatan Kertasari Kabupaten Bandung adalah seperti berikut.

Pertama; mahasiswa baru diwajibkan untuk berkontribusi menyediakan ribuan biji alpukat. Sejak tahun 2012, Unpas menyertakan setiap tahunnya, tidak kurang dari 20.000 biji alpukat yang dikumpulkan oleh 4.500 mahasiswa baru setiap tahunnya. Mahasiswa baru diwajibkan untuk membawa minimal 5 biji alpukat. Kemudian, ribuan biji alpukat itu ditanam di daerah hulu DAS Citarum, bekerjasama dengan PT. Perhutani dan Wahana Raksa Citarum yang berada petak 18 dan 19 daerah Neglasari, Cibeureum, Kecamatan Kertasari, Kabupaten Bandung. Sebetulnya, jumlah biji yang ditanam oleh mahasiswa Unpas mencapai 132.000 biji. Namun, dari jumlah itu hanya $30 \%$ yang tumbuh. Sampai saat ini, 22.000 pohon alpukat telah tumbuh dengan kondisi baik, dan 6.000 pohon yang masih di dalam polybag. Pohon alpukat itu hingga kini terus dijaga agar tumbuh besar.

Kedua; melaksanakan program Kuliah Kerja Nyata (KKN Tematik) yang dilaksanakan oleh Lembaga Pengabdian pada Masyarakat (LPM) Universitas Pasundan, dengan melibatkan mahasiswa semester 5 dari seluruh fakultas. KKN Tematik pada tahun 2018 adalah Citarum Harum. Rendahnya daya dukung DAS Citarum sebagai suatu ekosistem diduga merupakan salah satu penyebab utama terjadinya bencana alam yang terkait dengan air (hidrometeorologi). Kerusakan DAS dipercepat oleh peningkatan pemanfaatan sumberdaya alam sebagai akibat dari pertambahan penduduk dan perkembangan ekonomi, konflik kepentingan dan kurang keterpaduan antar sektor, antar wilayah hulutengah-hilir, terutama pada era otonomi daerah. Pada era otonomi daerah, sumberdaya alam ditempatkan sebagai sumber Pendapatan Asli Daerah (PAD).

Penanaman pohon adalah salah satu kegiatan penting yang harus dilaksanakan secara konseptual Lingkungan Hidup

628 
dalam menangani krisis lingkungan. Begitu pentingnya sehingga penanaman pohon sudah merupakan program nasional yang dilaksanakan di seluruh Indonesia. Penanaman pohon dalan arti luas adalah segala daya untuk memulihkan, memelihara, dan meningkatkan kondisi lahan agar dapat berproduksi dan berfungsi secara optimal baik sebagai penata air atau pelindung lingkungan. Oleh karena itu, salah satu caranya adalah dengan sosialisasi penanaman pohon alpukat yang berfungsi untuk pencegahan banjir dan longsor di DAS dan bantaran sungai Citarum. Program sosialisasi penanaman alpukat antara lain dimaksudkan untuk memberikan pengetahuan kepada masyarakat tentang bagaimana memanfaatkan pohon alpukat sebagai upaya untuk reboisasi dan dapat menghasilkan nilai tambah ekonomi keluarga.

Ketiga; karena sebagian besar mata pencaharian masyarakat desa-desa di Kecamatan Kertasari adalah buruh tani, maka Unpas juga melakukan pelatihan teknologi pengolahan limbah sayur. Selama ini, limbah sayur seperti tomat, kol, wortel yang busuk atau tidak terjual dibuang begitu saja. Limbah menyebabkan bau busuk dan mengotori lingkungan. Oleh karena itu, LPM Unpas dan bersama tim dosennya memberi pelatihan teknologi pengolahan limbah sayur untuk diolah menjadi pelet. Hasilnya cukup bagus, limbah sayur bisa bermanfaat bagi masyarakat.

\section{HASIL DAN PEMBAHASAN}

\section{Gambaran Umum Lokasi Pengabdian}

Kecamatan Kertasari merupakan salah satu wilayah di Kabupaten Bandung, Provinsi Jawa Barat yang memiliki luas lahan 15.112, 207 Hektar (Ha). Selain itu, kecamatan ini juga memiliki kekayaan alam yang cukup berlimpah dengan bidang pengembangan perekonomian yang menjadi mata pencaharian utama masyarakat setempat meliputi bidang pertanian, perkebunan, peternakan dan perdagangan. Pertumbuhan penduduk di Kecamatan Kertasari pada saat ini menunjukkan kecenderungan yang semakin bertambah dengan data jumlah penduduk sebanyak 66.831 Orang, terbagi antara 20.398 Kepala Keluarga (KK). Adapun komposisi jenis kelamin mepiputi jumlah penduduk Laki-laki
33.881 orang, dan penduduk perempuan 32.950 orang (Monografi Kecamatan Kertasari, 2018).

Kertasari merupakan wilayah kecamatan yang paling ujung selatan di Kabupaten Bandung. Adapun Kabupaten Bandung merupakan salah satu wilayah tertua di Provinsi Jawa Barat yang dulunya di kuasai oleh Kerajaan Kartanegara sebagai wilayah Pasundan. Kcamatan Kertasari dengan wilayah yang cukup luas memiliki 7 desa yaitu: Cibeureum, Sukapura, Tarumajaya, Cihawuk, Cikembang, Santosa, dan Neglawangi. Berdasarkan data Badan Penelitian Statistik (BPS Kabupaten Bandung, 2018), Dari 31 kecamatan yang ada di Kabupaten Bandung, Kertasari merupakan kecamatan tertinggal dengan peringkat Indeks Pembangunan Masyarakat (IPM) ke 30. IPM merujuk pada 3 bidang pembangunan yaitu: Pendidikan, Kesehatan, dan Ekonomi. Bidang pendidikan merupakan bidang yang paling tertinggal dengan peringkat ke 31; bidang kesehatan berada di peringkat ke 17; dan bidang ekonomi berada di peringkat ke 28 .

Kemiskinan merupakan persoalan utama masyarakat di Kecamatan Kertasari. Kondisi perekonomian Kecamatan Kertasari yang tergolong tertinggal di Kabupaten Bandung ini dipengaruhi oleh banyak faktor, bukan hanya karena letak geografisnya yang paling selatan, tetapi ada faktor lain seperti kualitas sumberdaya manusia yang relative rendah, dan insfratruktur yang buruk juga menjadi penghambat bagi kemajuan ekonomi dan percepatan pembangunan. Pada akhirnya timbullah sikap-sikap individualis pada sebagian besar masyarakatnya, dan kondisi tersebut mempunyai dampak social yaitu tidak adanya kejasama pada masing-masing warga.

\section{Pentingnya Menjaga Ekosistem Hulu DAS Citarum}

Sungai Citarum merupakan sungai terpanjang di Jawa Barat, yang mengalir dari pegunungan Bandung Selatan sampai ke pesisir Karawang sejauh 269 Kilometer. Karena debitnya yang besar, aliran Sungai Citarum dibendung menjadi 3 waduk besar yang berfungsi sebagai pemasok listrik se Jawa dan Bali. Ketiga Waduk tersebut antara lain Saguling, Cirata, dan Jatiluhur, yang menghasilkan listrik sebesar 1.400 Mega Watt, 
untuk kebutuhan Jawa dan Bali. Dari ketiga waduk tersebut, juga mengaliri irigasi sawah seluas 420.000 hektar. Selain itu air sungai Citarum juga menjadi sumber air baku bagi Kota Bandung, Cimahi, Karawang, Bekasi, dan DKI Jakarta.

Sejak awal jaman Kerajaan Hindu-Budha Tarumanegara pada abad ke-4 hingga pemerintah Kolonial Belanda, sungai ini menjadi jalur transportasi utama yang menghubungkan daerah pedalaman dengan pesisir untuk mengangkut hasil pertanian. Sungai Citarum telah memiliki peran penting sejak jaman dahulu kala sebagai jalur perdagangan dan peradaban manusia. Demikian pula halnya pada masa sekarang, Sungai Citarum menjadi asset penting bagi pembangunan.

Namun sayangnya, kisah keagungan Sungai Citarum telah terganggu akibat perilaku masyarakat yang tidak memuliakannya. Status kualitas air Sungai Citarum saat ini berada pada tingkat yang mengkhawatirkan, karena badan air sungai kini mengandung berbagai jenis kontaminan yang berasal dari berbagai sumber. Bahkan dinyatakan sebagai salah satu sungai terkotor di dunia (Birry, AS; Meutia, H, 2012).

Akibat ulah masyarakat yang membuang sampah sembarangan, dan menjadikan Sungai Citarum sebagai tempat pembuangan limbah pabrik, dan penggundulan hutan yang telah membuat kualitas air Citarum menurun drastis hingga tidak layak pakai. Hulu DAS Citarum mengalami rusak parah. Tahun 2009 Puslitbang Sumber Daya Air Kementerian PUPR mencatat, mata air di hulu Citarum ada 300 buah, namun pada 2015 tinggal 144 buah. Pohon-pohon di hutan kawasan hulu DAS Citarum hampir habis ditebang. Kawasan kritis dan sangat kritis ini telah mencapai 80 ribu hektar (http://psda.jabarprov.go.id/Berita/190.html).

Namum anehnya, masyarakat seolah-olah tak menghiraukan kerusakan ekosistem hulu DAS Citarum. Mereka tidak akan tahu apa yang akan terjadi pada masa mendatang jika ekosistem hulu DAS Citarum dibiarkan mengalami degradasi fungsi. Jika hutan mulai menipis, potensi terjadinya bencana alam pun akan semakin besar. Hal itu terjadi antara lain karena pertumbuhan jumlah penduduk, sehingga mereka memerlukan lahan yang dimanfaatkan untuk kegiatan pertanian yaitu menanam berbagai jenis sayuran. Mata pencaharian utama warga desa-desa di Kecamatan Kertasari terdiri dari buruh tani, buruh ternak, karyawan PTPN VIII, Karyawan PT. Lonsum, petani, peternak, dengan rata-rata pendapatan perkapita yang masih tergolong rendah (Profil Potensi Desa Tarumajaya, Kecamatan Kertasari, 2017).

Kompleknya permasalahan hulu DAS Citarum belum ada solusi yang baik dan ideal. Masyarakat Kecamatan Kertasari pada umumnya merupakan para pelaku tani sayur semusim. Karena jumlah lahan tetap, sementara jumlah penduduk terus bertambah, maka lahan milik Perhutani seluas 1050 Hektar akhirnya di garap oleh masyarakat untuk bercocok tanam. Lahan tersebut berfungsi sebagai hutan lindung, tetapi untuk menambah mata pencahariannya maka penyerobotan lahan terus berlangsung sejak tahun 1999, yaitu ketika PTPN VIII habis HGUnya.

Kawasan konservasi milik perkebunan yang di serobot oleh masyarakat digunakan untuk bercocok tanam sayur semusim. Akibatnya, terjadi sedimentasi di DAS Citarum yang mendatangkan bencana banjir di 15 dari 31 kecamatan di Kabupaten Bandung tergenang air setinggi 80-300 centimeter. Beberapa kecamatan bahkan tergolong parah, bahkan bisa dikatakan lumpuh, di Bojongsoang, Baleendah, Ciparay, dan Majalaya, Begitu juga Dayeuhkolot, Pameungpeuk, Katapang, dan Banjaran, wilayah itu tak bisa dilewati karena ketinggian air mencapai 3 meter.

Karena Sungai Citarum memiliki peran yang sangat strategis, maka Presiden Joko Widodo perlu mencanangkan "Penanggulangan Pencemaran dan Kerusakan DAS Citarum" di Situ Cisanti, Desa Tarumajaya, Kecamatan Kertasari Kabupaten Bandung, pada Kamis 22 Pebruari 2018. Situ Cisanti adalah hulu DAS Citarum. Pencanangan ini sekaligus menjadi payung hukum dalam pelaksaan program supaya penanganan DAS Citarum dapat diselesaikan oleh semua level pemerintahan maupun seluruh masyarakat dari hulu sampai hilir. Pengelolaan ekosistem DAS Citarum dilaksanakan secara terintegrasi meliputi program-program: (a) Penataan ruang; (b) Pengedalian erosi di hulu DAS 
dengan vegetasi; (c) Pengendalian alih fungsi lahan; (d) Pengendalian perijinan pemanfaatan lahan; (e) Pengendalian kualitas air sungai; (f) Kelembagaan Otoritas DAS Citarum; (g) Pembuatan peta kawasan lindung; dan (h) Peningkatan kapasitas dan partisipasi masyarakat untuk konservasi hulu DAS (Dinas Lingkungan Hidup Jawa Barat, 2018). Kunci sukses dari program tersebut adalah integrasi semua kementerian, lembaga, pemerintah pusat, pemerintah provinsi, pemerintah kabupaten dan kota.

\section{Revitalisasi}

Pengertian revitalisasi adalah upaya untuk memvitalkan kembali suatu kawasan atau bagian kota yang dulunya pernah vital dalam mendukung kehidupan, akan tetapi kemudian mengalami kemunduran atau degradasi. Skala revitalisasi bias berada pada tingkatan makro dan mikro. Proses revitalisasi sebuah kawasan mencakup perbaikan aspek ekologi, aspek ekonomi, dan aspek sosial budaya. Pendekatan revitalisasi harus mampu mengenali dan memanfaatkan potensi lingkungan seperti sejarah, makna, keunikan lokasi, dan citra tempat (Danisworo, 2002).

Dengan diresmikannya Program Revitalisasi Hulu DAS Citarum di Kecamatan Kertasari, maka akan ada dampak negatif terhadap sebagian besar kegiatan ekonomi masyarakat lokal. Lahan kritis dan sangat kritis milik negara di Hulu DAS Citarum sekitar 7.200 hektare akan dihijaukan kembali. Padahal sebelumnya, masyarakat setempat menggunakan lahan milik negara tersebut untuk ditanami sayuran, ada kol, kentang, wortel dan beragam jenis tanaman sayur semusim sebagai unggulan pendapatan bagi mayoritas masyarakat. Hal ini berarti akan ada sejumlah besar warga masyarakat yang tergusur matapencahariannya.

Akibatnya akan timbul masalah kemiskinan bagi warga masyarakat di Kecamatan Kertasari secara umum. Dampak negatif terhadap masalah ekonomi lainnya yaitu sumber matapencaharian ekonomi masyarakat yang menempatkan 2794 $(64,45 \%)$ KK yang bekerja menjadi buruh tani dengan upah Rp. 20.000 untuk laki-laki dan Rp. 15.000 untuk perempuan setiap harinya dalam waktu kerja 5 jam dari pukul 07.00 s/d 12.00 (adzan dzuhur). Kondisi matapencaharian seperti ini semakin mempertegas kemiskinan yang terjadi di desa-desa Kecamatan Kertasari. Keadaan tersebut tidak sebanding dengan penguasaan tanah BUMN seluas 1200 Ha oleh PTPN VIII. Demikian juga halnya dengan Perum Perhutani, lahan seluas 819,9 Hektar hanya mempekerjakan hanya 509 KK. Dalam penguasaan tanah badan usaha milik swasta seperti PT. Lonsum seluas 627,4 Ha hanya mampu mempekerjakan 292 KK.

Selain itu, timbul masalah kesenjangan sosial, karena Hulu DAS Citarum di kelilingi oleh Geotermal Raksasa. Dari Wilayah Selatan ada Pengeboran panas bumi yakni PT. Star Energi pada perbatasan antara Pangalengan-Kertasari, kemudian dari sebelah Timur ada PT. Chevron pada perbatasan Garut-Kertasari, dan pengeboran panas bumi daerah Kamojang yang di kelola oleh PT. Pertamina. Masyarakat Kecamatan Kertasari tidak mampu memperoleh kesempatan kerja di sector formal pada perusahaan

tersebut (http://psda.jabarprov.go.id/Berita/190.html). Hal ini antara lain karena masyarakat setempat merasa bahwa ada keterbatasan pendidikan dan ketrampilan yang dimiliki masih rendah.

Presiden Joko Widodo menyatakan bahwa program revitalisasi DAS Citarum bukanlah pekerjaan mudah, tidak bisa diselesaikan hanya dalam waktu singkat. "Sudah kita hitung bahwa pekerjaan besar ini dari hulu, tengah, sampai hilir akan diselesaikan, insya Allah dalam tujuh tahun," demikian pernyataan Presiden Joko Widodo. Program revitalisasi harus dilaksanakan secara terintegrasi oleh pemerintah pusat, pemerintah provinsi, hingga pemerintah kabupaten dan kota.

Program revitalisasi Citarum tidak hanya untuk memperbaiki lingkungan, melainkan juga menyumbang pertumbuhan ekonomi. Terlebih lagi, ketimpangan penguasaan lahan dari dulu hingga sekarang menjadi akar permasalahan sengketa lahan maupun konflik sosial di lingkungan masyarakat dalam memenuhi kebutuhan lahan untuk pertanian dan pemukiman. Wilayah yang telah ditetapkan sebagai kawasan lindung dapat menghadapi ancaman dan gangguan terhadap lahan hutan berupa perambahan, penebangan liar, dan alih fungsi lahan terus meningkat dari waktu ke waktu. Hal ini disebabkan oleh berbagai faktor, baik dari sisi

$$
\text { Lingkungan Hidup }
$$


pengelola kawasan hutan yang masih belum optimal dalam melaksanakan peran masyarakat yang tinggal di sekitar hutan, maupun dari sisi masyarakat yang tingkat kesadaran akan nilai-nilai pelestarian masih sangat minim (Diana; Pasha, 2015).

Oleh karena itu, untuk menangani permasalahan hulu DAS Citarum perlu mengeksplorasi kearifan lokal. Hal ini misalnya dengan memunculkan tokoh masyarakat Sunda yang sangat dikenal, yaitu si Kabayan Zaman Now untuk mempercepat pemulihan Kawasan Hulu DAS Citarum, dengan melibatkan seluruh komponen masyarakat dari hulul maupun hilir. UNPAS sebagai bagian dari komponen stakeholder telah terlibat pada kegiatan revitalisasi lingkungan di hulu DAS Sungai Citarum. UNPAS memandang bahwa penyelamatan hulu sangat penting untuk menjaga ekosistem lingkungan di hilirnya.

\section{Penanaman Pohon Alpukat}

Sungai Citarum merupakan asset sangat vital dan strategis khususnya bagi penduduk DKI Jakarta dan Provinsi Jawa Barat karena: (a) Masyarakat DKI Jakarta mengkonsumsi air yang bersumber dari Sungai Citarum mencapai 80 persen; (b) Sepanjang DAS digunakan oleh masyarakat untuk berbagai kegiatan social dan ekonomi; (c) Budidaya perikanan air tawar; (d) Mengairi irigasi 420.000 hektar sawah di Karawang, Purwakarta, Subang, dan Indramayu. Oleh karena itu, perlu ada kegiatan massal diperlukan untuk membangun kesadaran masyarakat agar memiliki semangat menjaga lingkungan dan menumbuhkan budaya cinta sungai.

Pemerintah Kabupaten Bandung telah meluncurkan gerakan "Sabilulungan Tanam Pohon Kesayangan (Satapok)" yang berlokasi di lahan Perum Perhutani petak 73, wayang Windu Pangalengan Desa Tarumajaya Kecamatan Kertasari. Gerakan tersebut dilakukan, selain untuk menyelamatkan kondisi sungai Citarum saat ini juga sebagai evaluasi terhadap kegiatan penghijauan masa lalu. Gerakan Satapok harus memastikan kualitas dan kualitas pohon yang ditanam dapat hidup dan menghasilkan sesuatu. Sehingga selain menjaga ekosistim kehidupan, akan ada dampak manfaat bagi kesejahteraan masyarakat yang merawatnya.
Dikawasan hulu DAS Citarum, di Situ Cisanti di petak 73, menjadi lokasi arboretum. Arboretum merupakan suatu kawasan untuk mengembalikan pungsi vegetasi dengan penanaman kembali dengan tanaman endemik yang sudah hilang.

UNPAS sudah ikut menghijaukan wilayah hulu DAS Citarum, bahkan jauh sebelum adanya program Citarum Harum. Dari hasil studi pada Progam Kemitraan Masyarakat, yaitu PKM BUMDES TARUMAJAYA: PELATIHAN MANAJEMEN EKOWISATA SITU CISANTI PADA PROGRAM REVITALISASI HULU DAS CITARUM (DRPM Kemenristek Dikti Juli September 2019), diketahui bahwa di Kawasan hulu DAS Citarum pohon-pohonnya hampir habis ditebang. Kawasan kritis dan sangat kritis telah mencapai 80 ribu hektar.

Untuk lebih menghijaukan kembali daerah hulu DAS Citarum, Lembaga Pengadian Masyarakat (LPM) UNPAS menyediakan 25.000 pohon kopi yang akan ditanaman oleh ratusan mahasiswa di tiga desa binaan yaitu Neglasari, Cibereum, dan Tarumajaya yang berada di Kecamatan Kertasari Kabupaten Bandung. Komitmen UNPAS untuk ikut serta melestarian hulu DAS Citarum dilatarbelakangi oleh kondisi lingkungan yang mengalami kerusakan. Sedimentasi di bagian hulu telah menyebabkan banjir di bagian hilir.

Sementara itu, puluhan ribu pohon alpukat yang ditanam sejak tahun 2012 oleh mahasiswa UNPAS sebagai kegiatan untuk pelestarian lingkungan di hulu DAS Citarum. Sampai saat ini, jumlah biji alpukat yang ditanam oleh UNPAS mencapai 132.000 biji. Namun, dari jumlah tersebut, hanya $30 \%$ yang tumbuh, sementara sisanya mati. Pohon alpukat itu hingga kini terus dijaga agar tumbuh besar. Terdapat 22.000 pohon alpukat telah tumbuh dengan baik, dan 6.000 masih di dalam polybag. Menurut Rektor UNPAS pada masa yang akan datang, Kecamatan Kertasari dapat menjadi sentra alpukat. 


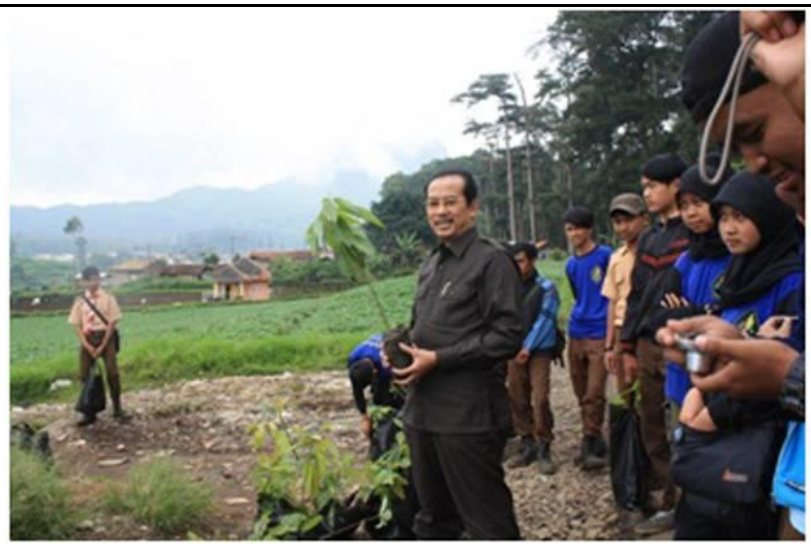

Gambar 1. Rektor UNPAS memimpin penanaman pohon alpukat Bersama mahasiswa baru

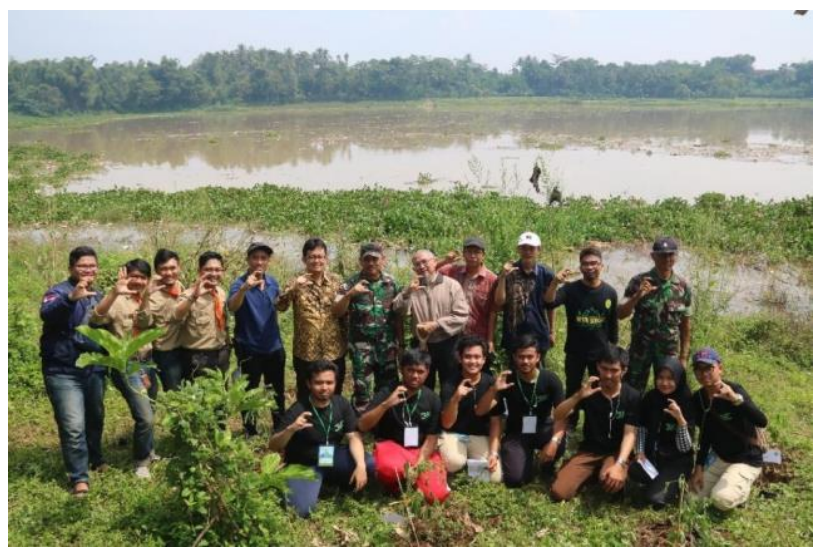

Gambar 2. Mahasiswa Bersama dosen UNPAS

Program pelestarian hulu DAS Citarum tersebut dilakukan oleh dosen dan mahasiswa UNPAS. Setiap mahasiswa baru, pihaknya mewajibkan untuk membawa lima biji alpukat. Setiap tahun, UNPAS rata-rata menerima 4.500 mahasiswa baru. Dipilihnya pohon alpukat karena sifatnya yang kokoh dan bisa mengikat tanah. Hal ini karena minimnya pohon yang bisa mengikat tanah di bagian hulu, akan membuat tanah masuk ke badan sungai. Akibatnya, terjadi pendangkalan di sungai dan banjir pun datang. Selama ini, penanganan terhadap bencana banjir akibat meluapnya sungai lebih banyak dilakukan di lokasi bencana. Oleh karena itu, lebih baik memperbaiki sumber atau penyebab dari bencana itu, maka UNPAS memilih untuk menyelamatkan bagian hulu DAS Citarum.
Selain itu, UNPAS juga telah mengadakan kerja sama dengan Perum Perhutani sebagai pemilik lahan, untuk ditanami pohon alpukat. Pada periode berikutnya, di sela-sela pohon alpukat dapat ditanami tanaman jangka pendek untuk menambah penghasilan masyakat. Selain melakukan pelestarian di hulu DAS Citarum, UNPAS secara khusus juga terlibat dalam menjaga Citarum di Sektor 6. Program Citarum Harum ke depan bisa melibatkan semua perguruan tinggi, agar dapat dikerahkan ke semua sektor.

Di desa Cibereum dan Kertasari, UNPAS juga melakukan pelatihan teknologi untuk mengolah limbah sayur menjadi pelet. Selama ini, limbah sayur seperti tomat, kol, wortel yang busuk dan tidak dapat terjual dibuang begitu saja. Limbah sayur tersebut menyebabkan bau busuk dan mengotori lingkungan.

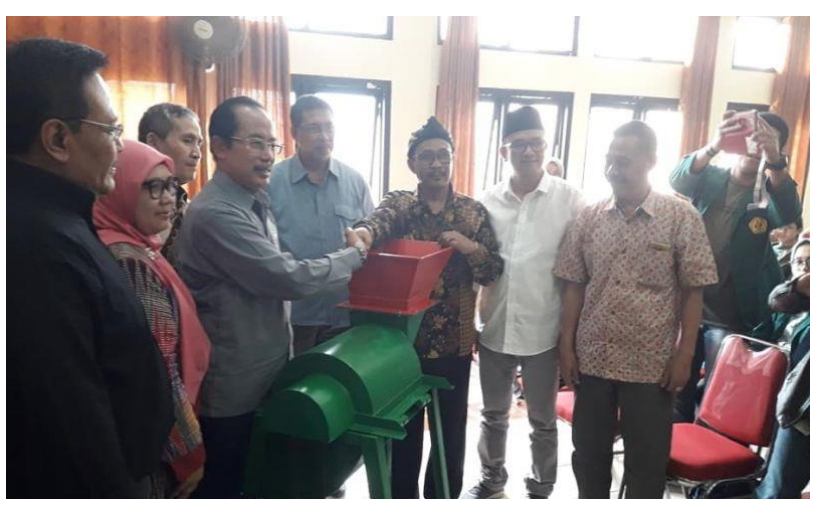

Gambar 3. Penyerahan mesin pengolah limbah sayur

Begitu juga limbah sampah domestic warga yang dibuang ke badan sungai telah menyebabkan kondisi air sungai tidak sehat dan menimbulkan penyakit.

\section{KESIMPULAN}

Hulu DAS Citarum mengalami rusak parah. Di hilir Citarum, sampah organik dan anorganik mencapai 20.462 ton per hari. Di sekitar Citarum ada 1.900 industri penghasil limbah, dengan 90 persennya Instalasi pengelolaan air limbah (IPAL) belum selesai, sehingga menghasilkan 340.000 ton limbah cair per harinya. Padahal Sungai Citarum mempunyai fungsi yang sangat vital dan strategis untuk mendukung kehidupan masyarakat Indonesia dengan jumlah penduduk paling padat, yaitu DKI Jakarta dan provinsi Jawa Barat. 
Oleh karena itu, Penanggulangan Pencemaran dan Kerusakan di hulu DAS Citarum harus menjadi prioritas program revitalisasi. Diperlukan Gerakan massal untuk membangun kembali semangat menjaga lingkungan dan menumbuhkan budaya cinta sungai, yang melibatkan seluruh elemen masyarakat. UNPAS telah berpartisipasi aktif dalam pemeliharaan hulu DAS Citarum sejak 2012, dengan berkontribusi menyediakan ribuan biji alpukat. Setiap tahunnya, tidak kurang dari 20.000 biji alpukat dikumpulkan dari 4.500 mahasiswa baru. Setiap mahasiswa wajib membawa 5 biji alpukat, kemudian ditanam di daerah hulu Sungai Citarum, di tiga desa binaan Kecamatan Kertasari Kabupaten Bandung, yakni Neglasari, Cibeureum, dan Tarumajaya, di Kecamatan Kertasari, Kabupaten Bandung.

\section{UCAPAN TERIMAKASIH}

Ucapan terimakasih disampaikan kepada DPRM Kemenristek Dikti yang telah memberikan kontribusi dana hibah dalam pelaksanaan kegiatan Pengabdian Kepada Masyarakat (PKM) tahun anggaran 2019. Ucapan terima kasih juga disampaikan kepada Lembaga Pengabdian pada Masyarakat (LPM) Universitas Pasundan yang telah mendukung kegiatan PKM. Demikian pula disampaikan terima kasih kepada para Kepala Desa Negkasari, Cibereum, dan Tarumajaya di Kecamatan Kertasari Kabupaten Bandung atas kerjasama yang sangat baik.

\section{REFERENSI}

Badan Pusat Statistik. 2011. Luas Daerah Pengaliran dan Debit dari Beberapa Sungai yang Daerah Pengalirannya Lebih dari $1.000 \mathrm{~km} 2,2000$ 2011.

Badan Pengelolaan Lingkungan Hidup Daerah (BPLHD) Provinsi Jawa Barat. 2010. Original Title : Status Lingkungan Hidup Daerah. Translated : Regional Environmental Status. Sections : Industrial activities with water contamination possibility.
Birry, Ahmad Ashov; Hilda Meutia. 2012. Bahan Beracun Lepas Kendali, Sebuah Potret Pencemaran Bahan Kimia Berbahaya dan Beracun di Badan Sungai Serta Beberapa Titik Pembuangan Industri Tak Bertuan, Studi Kasus Sungai Citarum. GREENPEACE Asia Tenggara; WALHI Jawa Barat.

Danisworo, 2002. Pengertian Revitalisasi. (Online) http://makalahdanskripsi.blogspot.com/. Diakses pada 30 Juli 2018.

Diana, D.; Pasha, G. K. 2015. Pelestarian dan Peran Masyarakat di kawasan Situ Cisanti. GEA Jurnal Pendidikan Geografi. Volume 15, Nomor 1, April 2015.

Eplerwood, M. 1999. The Ecotourism Society'-an International NGO Commited to Sustainable Development. Tourism Recreation Research 24.

Fandeli, C; Muchlison. 2000. Pengusaha Ekowisata. Fakultas Kehutanan Universitas Gadjah Mada Yogyakarta.

Haryanto, T.J. 2014. Model Pengembangan Ekowisata dalam Mendukung Kemandirian Ekonomi Daerah. Studi Kasus Provinsi DIY. KAWISTARA. Volume 4 No. 3, 22 Desember 2014.

https://jurnal.ugm.ac.id/kawistara/article/viewF ile/. Diakses 21/08/2018.

Laretna, Adisakti. 2005. Revitalisasi Kawasan Pusaka di Berbagai Belahan Bumi Harian kompas. Minggu 13 November.

Profil Potensi Desa Tarumajaya. 2017.

Terangna. 1991. Water pollution. The course of the environmental impact assessment.Institute of Ecology, Padjadjaran University.

https://www.republika.co.id/. Kondisi Citarum di Hulu dan Hilir. Diakses 20/08/2018.

http://citarum.org/info-citarum/berita-artikel. Diakses 19/08/2018.

http://www.pikiran-rakyat.com/bandungraya/2012/07/27/197435/70-persen- 
pencemaran-citarum-akibat-buangan-limbahdomestik. Diakses 15/08/2018.

https://www.dw.com/id/bagaimana-sungai-jermanbisa-bersih/. Diakses 19/08/2018.

https://citarum.org/info-citarum/berita-artikel.

Diakses 20/08/2018.

http://www.jasatirta2.co.id/news/presiden-jokowitinjau-situ-cisanti-hulu-sungai-citarum. Diakses 10/08/2018. https://www.rappler.com/indonesia/berita/194162misi-besar-atasi-pencemaran-sungai-citarum. Diakses 08/08/2018.

https://kicknews.today/2017/03/20/membangunbumdes/. Diakses 16/07/2018.

http://psda.jabarprov.go.id/Berita/190.html. Diakses $\underline{21 / 08 / 2018}$. 